\title{
Analyses of Chloroplast Genomic and Morphological Evolutionomy of Yulania Sprengeri and Two New Confusable Species (Magnoliaceae)
}

\author{
Da-Li Fu ${ }^{1,4, ~ *, ~ B i n g-H o n g ~ X i o n g ~}{ }^{2, ~ *}$, Xun Chen ${ }^{3,}$, Wen-Xiao Tian ${ }^{5}$, Lei Du ${ }^{6}$ \\ ${ }^{1}$ Non-timber Forestry Research and Development Center, Chinese Academy of Forestry, Zhengzhou, China \\ ${ }^{2}$ South China Botanical Garden, Chinese Academy of Science, Guangzhou, China \\ ${ }^{3}$ Science and Technology Department of Guizhou Province, Guiyang, China \\ ${ }^{4}$ Key Laboratory of Non-timber Forest Germplasm Enhancement \& Utilization of National Forestry and Grassland Administration, Zhengzhou, \\ China \\ ${ }^{5}$ Wildlife Reserve Station of Nanzhao County, Nanzhao, China \\ ${ }^{6}$ Forest Station of Anchang of Beichuan County, Beichuan, China
}

Email address:

fu_dali@163.com (Da-Li Fu),wdxiongbh@163.com (Bing-Hong Xiong), chenxunke1956@163.com (Xun Chen)

${ }^{*}$ Corresponding author

\section{To cite this article:}

Da-Li Fu, Bing-Hong Xiong, Xun Chen, Wen-Xiao Tian, Lei Du. Analyses of Chloroplast Genomic and Morphological Evolutionomy of Yulania Sprengeri and Two New Confusable Species (Magnoliaceae). American Journal of Agriculture and Forestry. Special Issue: The New Evolutionary Theory \& Practice. Vol. 7, No. 5, 2019, pp. 212-223. doi: 10.11648/j.ajaf.20190705.17

Received: August 28 , 2019; Accepted: September 16, 2019; Published: September 23, 2019

\begin{abstract}
To scientifically solve the taxonomical confusion of Yulania sprengeri (Pamp.) D. L. Fu in the world, the chloroplast genomic sequences of four confusable species were assembled and compared with the other species of Yulania Spach by means of the typical algorithm. The results indicated that the evolutionary system of Yulania Spach includes four natural sections: Y. sect. Yulania, Y. sect. Buergeria (Sieb. \& Zucc.) D. L. Fu, Y. sect. Rosula D. L. Fu, sect., nov., and Y. sect. Tulipastrum (Spach) D. L. Fu, which all have the same boundaries: PHS $(17 \mathrm{bp})=0.96$. The species Y. sprengeri (Pamp.) D. L. Fu belong to sect. Yulania, but several confusable species such as Y. diva (Stapf. ex Dandy) D. L. Fu, sp. transl. nov., Y. urceolata D. L. Fu, B. H. Xiong et X. Chen, sp. segregat. nov., Y. pendula D. L. Fu, sp. nov. and Y. viridula D. L. Fu, T. B. Zhao et G. H. Tian belong to the new section Rosula D. L. Fu. According to International Code of Botanical Nomenclature, Y. sprengeri (Pamp.) D. L. Fu is proposed for conservation and emended with the conserved type (D. L. Fu 2017100803, CAF). The misidentified epitype of Magnolia sprengeri, the illustration in Flora of Trees of China, differing taxonomically, selected as Lectotype, with almost equal specimen, paratype (D. L. Fu 2017093001, CAF) from Weining County, Guizhou province of China, was segregated as a new species, Y. urceolata D. L. Fu, B. H. Xiong et X. Chen. The other new confusable species, Y. pendula D. L. Fu, is described and illustrated based on the holotype (D. L. Fu 2012040201, CAF) from Sichuan province of China, which was once misidentified as Y. biondii (Pamp.) D. L. Fu or Y. sprengeri (Pamp.) D. L. Fu. The typci-evolutionary characters including diagnostic differences and particularity of the new section and two new species, are given respectively. The evolutionary system scientifically overcomes the partiality and subjectivity of past taxonomical systems of Yulania Spach of Magnoliaceae Juss.
\end{abstract}

Keywords: Typical Algorithm, Yulania Sect. Rosula, Yulania Sprengeri, Yulania Urceolata, Yulania Pendula, Evolutionomy, Typici-Evolutionary Character, New Taxa

\section{Introduction}

Yulania Spach [1-9] is the most primitive taxa of
Fructophyta D. L. Fu \& H. Fu [10], has a very important position and will play an important role in the evolutionomy of fruit plants. The genus is also difficult taxon and its resources 
have not yet been ascertained, for being tall trees, growing in the mountains with inconvenient transportation and having more cross-characters and profuse variations of most species, and some of them being very rare in number and very difficult to find. Of course, the slow progress of taxonomy of Yulania Spach is also related to the partiality and subjectivity of traditional plant taxonomy and modern phylogenetic theory. One example is the confusion of Y. sprengeri (Pamp.) D. L. Fu.

The species was published as Magnolia sprengeri Pamp. in Nouv. Giorn. Bot. Ital. in 1915 by R. Pampanini, a Italian botanist, based on the types collected from Mountain Wudang of Hubei province of China by P. C. Silvestri in 1912 and 1913 [11]. "there have been considerable nomenclatural and taxonomical difficulties concerning $M$. sprengeri and its infraspecific division...because the type material of $M$. sprengeri...consists only of flowering specimens, and it is not possible to determine the original colour of the dried tepals. Furthermore since the flowers of $M$. sprengeri are precocious, the specimens lack leaves [12]" But actually the original colour of tepals was not significant, some description of the species was neglected such as the gemma, branchlet and that $\mathrm{R}$. Pampanini had confirmed the species was close to $\mathrm{Y}$. salicifolia (Sieb. \& Zucc.) D. L. Fu [1, 7, 9].

Dr. J. E. Dandy published Magnolia diva Stapf ex Dandy in 1927 to try to solve the confusion of M. sprengeri Pamp. of the time. Sadly it was not accepted for it being toughly regarded as that both were the same species just based on flower characters. Now they can be easily distinguished by different hairs of the lower surfaces of their leaves. So a new translatable species of Yulania Spach could be confirmed that is:

Yulania diva (Stapf ex Dandy) D. L. Fu, sp. transl. nov.; Magnolia diva Stapf ex Dandy, in Millais, Magnolias, 51, 120 (1927); Stapf in Bot. Mag. sub t. 9116 (1927), insyn.; NIB, Flora of Qinling 1 (2): 338. 1974.

The first volume of Flora of trees of China published in 1983. Magnoliaceae Juss. were edited by Y. H. Liu, the famous botanist of the family [13]. The description and illustration of the species of Magnolia sprengeri (= Yulania sprengeri) were supplemented and improved. The elaborate illustration (Figure 4.1 to 3 ) should be regarded as the epitype of the species according ICBN (International Code of Botanical Nomenclature) [14], for it being widely accepted by botanical authorities, such as The World of Magnolias [15], Flora Reipublicae Popularis Sinicae Tomus [16], Magnolias and their allies [12], Magnolias of China [17], Flora Yunnanica [3], Flora of China [5], Shijie Yulanshu Zhiwu Ziyuan yu Zaipei Liyong [7], Shijie Yulanshu Zhiwu Zhongzhi Ziyuan Zhi [8], and Henan Yulan Zaipei [9].

Almost being identical to the illustration of the epitype of Y. sprengeri, a specimen was collected from Weining County of Guizhou province of China at alt. $2300 \mathrm{~m}$ in 2017 by D. L. Fu. For its foliar buds glabrous or pubescent, floral (mixed) buds villous differing from "gemmis foliiferis glabris vel ad apicem vix puberulis...alabastris longe sericeo-villosis" of Y. sprengeri Pamp. The suspicion that the illustration differ taxonomically should be scientifically verified. So four chloroplast genomic sequences of Y. sprengeri and three confusable species were assembled, which were compared with the other species of Yulania Spach by means of the typical algorithm based on the evolutionary continuity principle [10]. The results are as follows.

\section{Materials and Methods}

\subsection{Chloroplast Genome Sequencing, Assembly and Annotation}

The leaves of four species of Yulania Spach were collected: Y. sprengeri (Pamp.) D. L. Fu from Mountain Wudang of Hubei province, the new segregated species Y. urceolata D. L. $\mathrm{Fu}$, B. H. Xiong et X. Chen from cultivated plants in Zhengzhou City of Henan province, the new species Y. pendula D. L. Fu form Beichuan County of Sichuan province, Y. viridula D. L. Fu, T. B. Zhao et G. H. Tian from cultivated trees in Zhengzhou City of Henan province. Total genomic DNA was isolated from silica-dried leaves of four species using a modified CTAB method [18]. Using the Illumina Hiseq 2500 platform (Lemont, IL, USA), the high-throughput sequencing was performed after quantification and qualification, and the paired-end library being constructed. All remaining high quality sequences were assembled into contigs using de novo assembly after cleaning the raw data. Using the software SPAdes v3.9.0., the complete chloroplast genomes were assembled. The fully annotated genomes with circular map were drawn in OGDRAWv1.2 [19]. All four chloroplast genomes of Yulania Spach were deposited in the GenBank database.

\subsection{Evolutionary Analyses of Chloroplast Genomes}

Using evolutionary continuity principle of Evolutionomy [10], the morphological characters and the chloroplast genomes of four species of Yulania Spach were compared with other species of the genus. The typical algorithm is mainly adopted in the evolutionary analyses of chloroplast genomes, by comparing the phylogenetic similarity (PHS) between the designated type and objective species or taxon which can determine the relatively evolutionary relationships among different taxa. The formula is as follows:

$$
P H S=\frac{\text { SPHL }}{\mathrm{APHL}}
$$

PHS = phylogenetic similarity between the type and objective taxon; SPHL $=$ the number of same phylogenetic loci between the type and objective taxon; APHL = all number of phylogenetic loci of the type; statistics of phylogenetic loci using Nucleotide Barcodes (NB $\geqslant 17 \mathrm{bp}$ ). 


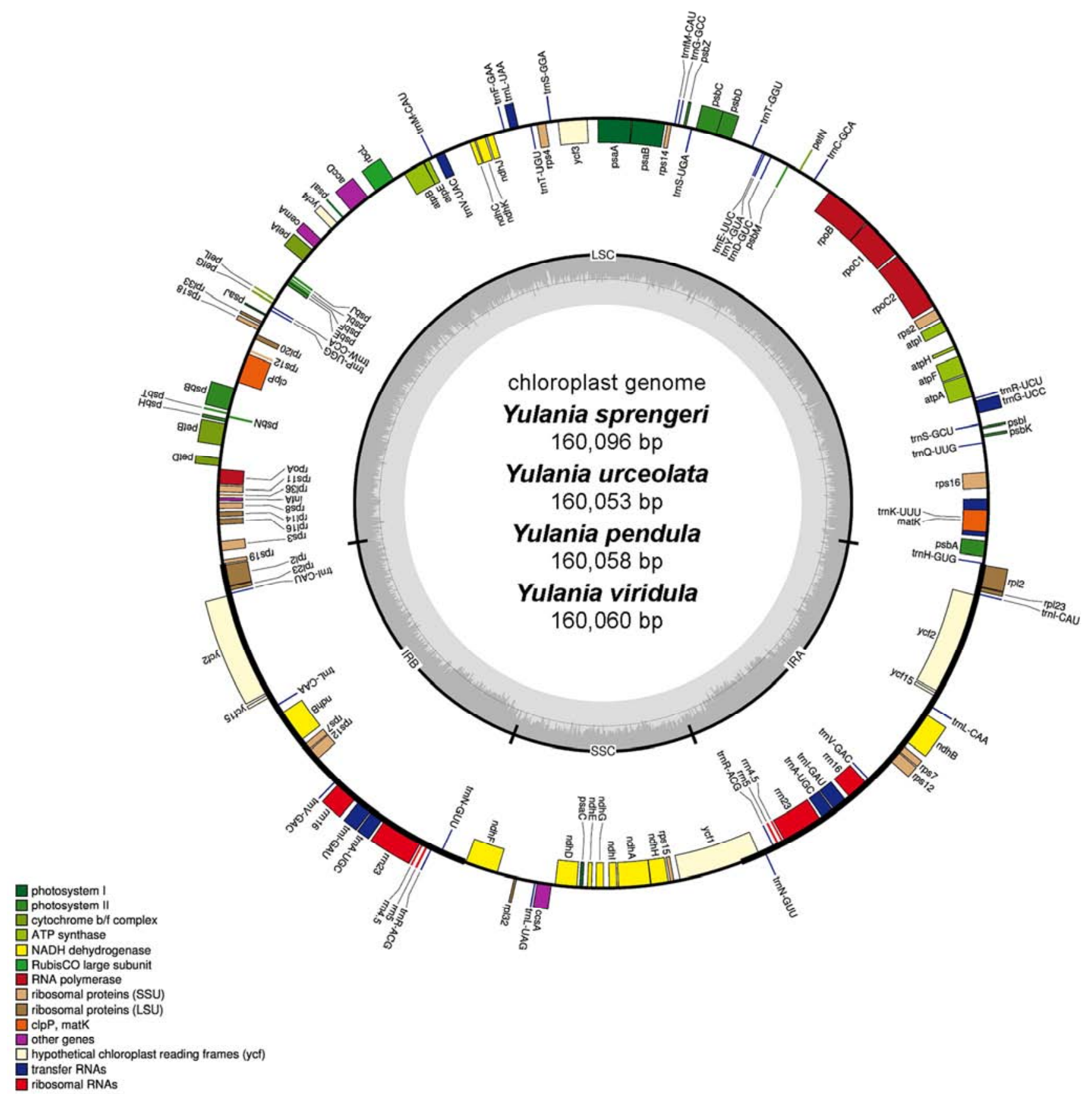

Figure 1. Chloroplast genome map of Yulania sprengeri (Magnoliaceae). The genes inside and outside the circle are transcribed in the clockwise and counterclockwise directions, respectively. Genes belonging to different functional groups are shown in different colors. The thick lines indicate the extent of the inverted repeats (IRA and IRB) that separate the genomes into small single-copy (SSC) and large single-copy (LSC) regions.

\section{Genomes of Four Species of Yulania Spach}

The chloroplast genomes of the four species of Yulania, similar to the chloroplast genomes of other species, include four parts: two inverted repeats, IRA and IRB, and the remaining LSC large single copy area and SSC small single copy area. The complete chloroplast genomes of Y. sprengeri, Y. urceolata, Y. pendula and Y. viridula are 160,096bp, $160,053 \mathrm{bp} 160,058 \mathrm{bp}$ and $160,060 \mathrm{bp}$ in length, respectively, which all are encoded 128 genes, include 83 protein coding genes, 8 rRNA genes and 37 tRNAs. atpF, rpoC1, trnL-UAA, trnV-UAC, petB, petD, rpl16, rpl2, $n d h \mathrm{~B}, \quad \operatorname{trnI}-\mathrm{GAU}$, trnA-UGC, $n d h \mathrm{~A}$, trnK-UUU, rps 16 , and trnG-UCC genes with an intron for each gene, $c l p \mathrm{P}$ and $y c f 3$ gene with two introns, and the rps 12 is trans-splicing gene, see Figure 1.

\section{Evolutionary System of Yulania Spach}

Although the genus Yulania had successfully been established in 1839 by E. Spach, the other genus Tulipastrum 
Spach, really being same, was also done at the same time by him. Moreover another genus Buergeria was done by P. F. v. Siebold \& J. G. Zuccarini in 1845. All these genera usually regarded as Magnolia L. The genus finally had become a natural genus by $\mathrm{D}$. $\mathrm{L}$. Fu [1] based on the results of morphology and DNA phylogeny.

Traditional taxonomical and phylogenic system sometimes are inevitably partial and subjective [10]. To establish a scientific system of the genus Yulania, the PHSs among different species were analyzed based on the chloroplast complete genomes of 14 species of the genus using the types of 4 species respectively: Y. sprengeri (Pamp.) D. L. Fu, Y. pendula D. L. Fu, Y. biondii (Pamp.) D. L. Fu and Y. acuminata (L.) D. L. Fu, and the results are shown in Table 1 to 4.

Table 1. PHS of chloroplast genomes between Y. sprengeri and other species of Yulania Spach.

\begin{tabular}{llll}
\hline Section & Species name and cpDNA number in NCBI & PHL /17bp & PHS \\
\hline Yulania & Yulania sprengeri & 133188 & 1 \\
Yulania & Yulania cylindrica & 132206 & 0.993 \\
Yulania & Yulania puberula & 132110 & 0.992 \\
Yulania & Yulania shizhenii & 132085 & 0.992 \\
Yulania & Yulania denudata_JN867577.1 & 131635 & 0.988 \\
Yulania & Yulania liliiflora_JX280397.1 & 129839 & 0.975 \\
Buergeria & Yulania salicifolia_NC023240.1 & 127539 & 0.958 \\
Rosula & Yulania diva?_NC023242.1 & 127295 & 0.956 \\
Rosula & Yulania urceolata & 127115 & 0.954 \\
Rosula & Yulania pendula & 127048 & 0.954 \\
Rosula & Yulania viridula & 126978 & 0.953 \\
Buergeria & Yulania biondii_KY085894.1 & 126776 & 0.952 \\
Buergeria & Yulania kobus_NC023237.1 & 126179 & 0.947 \\
Tulipastrum & Yulania acuminata_JX280391.1 & 124101 & 0.932 \\
\hline
\end{tabular}

Table 2. PHS of chloroplast genomes between Y. biondii and other species of Yulania Spach.

\begin{tabular}{llll}
\hline Section & Species name and cpDNA number in NCBI & PHL /17bp & PHS \\
\hline Buergeria & Yulania biondii_KY085894.1 & 133127 & 1 \\
Buergeria & Yulania salicifolia_NC023240.1 & 130028 & 0.977 \\
Buergeria & Yulania kobus_NC023237.1 & 129692 & 0.974 \\
Rosula & Yulania diva?_NC023242.1 & 127360 & 0.957 \\
Rosula & Yulania urceolata & 127188 & 0.955 \\
Rosula & Yulania pendula & 127169 & 0.955 \\
Rosula & Yulania viridula & 127122 & 0.955 \\
Yulania & Yulania sprengeri & 126780 & 0.952 \\
Yulania & Yulania cylindrica & 126763 & 0.952 \\
Yulania & Yulania puberula & 126743 & 0.952 \\
Yulania & Yulania shizhenii & 126700 & 0.952 \\
Yulania & Yulania denudata_JN867577.1 & 126315 & 0.949 \\
Yulania & Yulania liliiflora_JX280397.1 & 125953 & 0.946 \\
Tulipastrum & Yulania acuminata_JX280391.1 & 124082 & 0.932 \\
\hline
\end{tabular}

Table 3. PHS of chloroplast genomes between Y. pendula and other species of Yulania Spach.

\begin{tabular}{llll}
\hline Section & Species name and cpDNA number in NCBI & PHL /17bp & PHS \\
\hline Rosula & Yulania pendula & 133226 & 1 \\
Rosula & Yulania viridula & 132606 & 0.995 \\
Rosula & Yulania urceolata & 132534 & 0.995 \\
Rosula & Yulania diva?_NC023242.1 & 132434 & 0.994 \\
Buergeria & Yulania salicifolia_NC023240.1 & 127932 & 0.960 \\
Buergeria & Yulania biondii_KY085894.1 & 127166 & 0.955 \\
Yulania & Yulania sprengeri & 127048 & 0.954 \\
Yulania & Yulania cylindrica & 127039 & 0.954 \\
Yulania & Yulania puberula & 127039 & 0.954 \\
Yulania & Yulania shizhenii & 126989 & 0.953 \\
Yulania & Yulania denudata_JN867577.1 & 126585 & 0.950 \\
Buergeria & Yulania kobus_NC023237.1 & 126516 & 0.950 \\
Yulania & Yulania liliiflora_JX280397.1 & 126167 & 0.947 \\
Tulipastrum & Yulania acuminata_JX280391.1 & 124217 & 0.932 \\
\hline
\end{tabular}


Table 4. PHS of chloroplast genomes between Y. acuminata and other species of Yulania Spach.

\begin{tabular}{llc}
\hline Section & Species name and cpDNA number in NCBI & PHL /17bp \\
\hline Tulipastrum & Yulania acuminat_JX280391.1 & 132907 \\
Buergeria & Yulania salicifolia_NC023240.1 & 124741 \\
Rosula & Yulania diva?_NC023242.1 & 124376 \\
Rosula & Yulania urceolata & 124242 \\
Rosula & Yulania pendula & 124216 \\
Rosula & Yulania viridula & 124112 \\
Yulania & Yulania sprengeri & 124101 \\
Buergeria & Yulania biondii_KY085894.1 & 124077 \\
Yulania & Yulania cylindrica & 124021 \\
Yulania & Yulania puberula & 124015 \\
Yulania & Yulania shizhenii & 0.936 \\
Yulania & Yulania denudata_JN867577.1 & 0.935 \\
Buergeria & Yulania kobus_NC023237.1 & 0.935 \\
Yulania & Yulania liliiflora_JX280397.1 & 0.934 \\
\hline
\end{tabular}

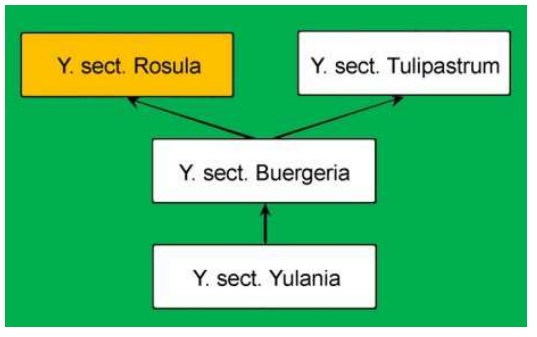

Figure 2. Evolutionary system of sections of Yulania Spach based on the chloroplast genomic and morphological evolutionomy.

It can be seen from Table 1 to 4 that using the types of Y. sprengeri (Pamp.) D. L. Fu, Y. biondii (Pamp.) D. L. Fu, Y. pendula D. L. Fu and Yulania acuminata (L.) D. L. Fu respectively, Yulania Spach obviously includes 4 natural sections: Y. sect. Yulania, Y. sect. Buergeria (Siebold \& Zucc.) D. L. Fu, Y. sect. Rosula D. L. Fu, sect., nov., and Y. sect. Tulipastrum (Spach) D. L. Fu., which all have the same boundaries: PHS (17bp) $>0.96$ (inner section) and PHS (17bp) $\leq 0.96$ (inter sections). It can also be confirmed that the species Y. sprengeri (Pamp.) D. L. Fu belongs to sect. Yulania, but several confusable species such as Y. diva (Stapf ex Dandy) D. L. Fu, Y. urceolata D. L. Fu, B. H. Xun et X. Chen, sp. segregat. nov., Y. pendula D. L. Fu, sp. nov., and Y. viridula D. L. Fu, T. B. Zhao et G. H. Tian. belong to the new section Rosula D. L. Fu. So, the confusion of Y. sprengeri are scientifically solved by the analysis of chloroplast genomic and morphological evolutionomy.

According the evolutionary continuity principle, based on PHS of 14 species of Yulania (Tables 1 to 4), the evolutionary system of the genus can be established as Figure 2 .

Four sections of Yulania Spach are described or emended as follows.

I. Yulania sect. Yulania

Magnolia sect. Yulania (Spach) Reichenbach in Der Dectsche Bot. 1: 192. 1841. p. p. Typus: Yulania conspicua Spach $=$ Yulania denudata (Desr.) D. L. Fu, J. Wuhan Bot. Res. 19 (3): 198. 2001; Magnolia denudata Desr. in Lam., Encycl. Bot. 3: 675. 1792 .

Deciduous trees and shrubs. Branchlets often purplish-red, two species yellowish-green (Y. verrucata and Y. sprengeri). Floral (mixed) buds larger to $5 \mathrm{~cm}$ long. Leaves obovate to elliptic, lower surfaces puberulent, pubescent, villous or tomentose. Flowers precocious or appearing with the leaves, sepals and petals often less than 12, cup-shaped. Fruit aggregates cylindric to ovoid.

The section includes about 11 species: Y. puberula D. L. Fu, Y. cylindrica (Wils.) D. L. Fu, Y. shizhenii D. L. Fu et F. W. Li, Y. sprengeri (Pamp.) D. L. Fu, Y. verrucata D. L. Fu, T. B. Zhao et S. S. Chen, Y. pilocarpa (Z. Z. Zhao et Z. W. Xie) D. L. Fu, Y. jigongshanensis (T. B. Zhao et al.) D. L. Fu, Y. denudata (Desr.) D. L. Fu, Y. pyriformis (T. D. Yang et T. C. Cui) D. L. Fu, Y. mirifolia D. L. Fu, T. B. Zhao et Z. X. Chen, Y. liliiflora (Desr.) D. L. Fu.

The species of this section are mainly distributed in Henan, Shanxi, Hubei, Anhui, Sichuan, Jiangsu, Zhejiang, Hunan, Jiangxi, Fujian, and other provinces of South China.

The species of this section are the most primitive taxa of fruit plants, and will play an important role in researching the evolutionomy of Magnoliaceae Juss. and Fructophyta D. L. Fu $\& \mathrm{H}$. Fu. Some species of this section, such as Y. puberula D. L. Fu, Y. shizhenii D. L. Fu et F. W. Li and Y. verrucata D. L. $\mathrm{Fu}, \mathrm{T}$. B. Zhao et S. S. Chen are in serve danger and very rare in species number, so it should be protected urgently.

II. Yulania sect. Buergeria (Sieb. \& Zucc.) D. L. Fu

J. Wuhan Bot. Res., 19 (3): 198. 2001. - Buergeria Sieb. \&Zucc., in Abh. Akad. Muench. 4 (2) 186. 1845. (Fl. Jap. Fam. 1: 78). - Magnolia sect. Buergeria (Sieb. \& Zucc.) Dandy in Camellias and Magnolias Rep. Conf. 73. 1950. Typus: Yulania stellata (Sieb. \& Zucc.) D. L. Fu, sp. transl. nov.; Buergeria stellata Sieb. \& Zucc. in Abh. Akad. Muench. 4 (2) 186. 1845; - Yulania stellata (Sieb. \& Zucc.) D. L. Fu, nom. illegit. (cit. illegit.), in G. H. Tian et al., Chin. Agr. Sci. Bull., 22 (5): 408. 2006; - Yulania stellata (Maxim.) N. H. Xia, nom. illegit. (laps. cit.) in Flora of China, vol. 7: 75. 2008; - Yulania tomentosa (Thunb.) D. L. Fu, (nom. rej.), J. Wuhan Bot. Res., 19 (3): 198. 2001.

Deciduous trees and shrubs. Branchlets often greenish, rare purplish (Y. stellata). Floral (mixed) buds often small to $3 \mathrm{~cm}$ long. Leaves elliptic to obovate, lower surfaces pubescent, villous or tomentose. Flowers precocious, often lageniform before spreading and tepals often less than $3 \mathrm{~cm}$ wide and exconvoluted after spreading. Fruit aggregates ovoid to cylindric. 
The section including about 7 species: Y. salicifolia (Sieb. \& Zucc.) D. L. Fu, Y. biondii (Pamp.) D. L. Fu, Y. axilliflora (T. B. Zhao et al.) D. L. Fu, Y. zenii (Cheng) D. L. Fu, Y. sinostellata (P. L. Chiu et Z. H. Chen) D. L. Fu, Y. kobus (DC.) Spach, Y. stellata (Sieb. \& Zucc.) D. L. Fu.

The species of this section are mainly distributed in China, Japan and Korea.

The species of this section are mainly cultivated as a main species for Xinyi, a Chinese traditional medicine.

III. Yulania sect. Rosula D. L. Fu, sect. nov. Fig. 4, 5.

Typus: Yulania campbellii (Hook. f. \& Thoms.) D. L. Fu, J. Wuhan Bot. Res., 19 (3): 198. 2001; Magnolia campbellii Wils. Hook. f. \& Thoms. Fl. Ind. 1: 77. 1855.

Large deciduous trees to $30 \mathrm{~m}$, barks gray and smooth. Branchlets often yellow or yellowish green, thick, stout, short, marked with horizontal and horse-shoe-like petiolescars and longitudinally fissured. Floral buds large to $7 \mathrm{~cm}$ long, pubescent, villous, tomentose or lanose (hairs to $9 \mathrm{~mm}$ long), apices often blunt. Leaves elliptic, elliptic-ovate, oblong-ovate, obovate or ovate, apices acuminate, rounded or obtuse, lower surfaces pubescent, villous or tomentose. Flowers precocious, large, showy, single, white, purple or red; petals often more than 12 and lotiform. Fruits cylindric often purplish-red at dehiscence.

The new section is easily confused with sect. Yulania, but its particularity such as branchlets often yellow marked with horizontal and horse-shoe-like petiolescars and flowers lotiform, which can be distinguished to the species of Y. sect. Yulania often with reddish purple branchlets with triangular \pm protrudent petiolescars or puberulent leaves, and cup-shaped flowers often with less than 12 petals and sepals.

The section including about 9 species: Yulania diva (Stapf ex Dandy) D. L. Fu, sp. transl. nov., Y. urceolata D. L. Fu, B. H. Xiong et X. Chen, sp. segregat. nov., Y. pendula D. L. Fu. sp. nov., Y. carnosa D. L. Fu et D. L. Zhang, Y. viridula D. L. Fu, T. B. Zhao et G. H. Tian, Y. sargentiana (Rehd. \& Wils.) D. L. Fu, Y. dawsoniana (Rehd. \& Wils.) D. L. Fu, Y. campbellii (Hook. f. \& Thoms.) D. L. Fu, Y. baotaina D. L. Fu, Q. Zhang et M. $\mathrm{Xu}, \mathrm{sp}$. nov. ined.

The species of this section are mainly distributed in Hubei, Shanxi, Gansu, Sichuan, Guizhou, Yunnan, Xizang and other provinces of Southwest China, and Bhutan, Burma, India, Nepal, etc., at an altitude of $1100 \sim 3300 \mathrm{~m}$ in broadleaf and conifer mixing forest.

The species of this section are mainly cultivated as for fancy garden trees for the beautiful flowers in the world, and also for Xinyi, a Chinese traditional medicine in China.

IV. Yulania sect. Tulipastrum (Spach) D. L. Fu

J. Wuhan Bot. Res., 19 (3): 198. 2001. - Tulipastrum Spach, Hist. Nat. Veg. Phan. 7: 481. 1839. - Y. subgen. Tulipastrum (Spach) T. B. Zhao et Z. X. Chen, in T. B. Zhao et al., Shijie Yulanshu Zhiwu Ziyuan yu Zaipei Liyong. 171-172. Typus: Yulania acuminata (L.) D. L. Fu, J. Wuhan Bot. Res., 19 (3): 198. 2001; Magnolia acuminata L., Syst. Nat. ed. 10 (2): 1082. 1759.

Large deciduous trees to $30 \mathrm{~m}$, barks gray-brown furrowed into ridges. Hornotini-branchlets reddish purple, marked with step-like petiolescars. Floral buds sericeous. Leaves elliptic to broadly ovate, apices often acuminate. Flower appearing with the leaves, often cup-shaped; tepals 9 often greenish to greenish-yellow, outer whorl 3 sepaloid. Fruit aggregates short, ovoid to cylindric. Seeds reddish-orange.

The section including only 1 species: Yulania acuminata (L.) D. L. Fu.

The species of this section are distributed in North America. A good species cultivated for garden or landscaping.

\section{Yulania Sprengeri and Two New Confusable Species}

\subsection{Yulania Sprengeri (Pamp.) D. L. Fu, Figure 3}

J. Wuhan Bot. Res., 19 (3): 198. 2001.; Magnolia sprengeri Pamp. in Nouv. Giorn. Bot. Ital. n. ser. 22: 295. 1915. Typus: Silvestri 4104 (Holotypus, FI, non vidi), D. L. Fu 2017100803 (Conserved type, CAF).

Magnolia elliptigemmata C. L. Guo et L. L. Huang, J. Wuhan Bot. Res., 10 (4): 325-327. fig. 1. 1992. Typus: C. L. Guo et L. L. Huang 087901 (IBSC); Y. H. Liu, in Flora Reipublicae Popularis Sinicae Tomus 30 (1): 136. 1996; Y. H. Liu ed., Magnolias of China. 58. fig. 2004. - Yulania elliptigemmata (C. L. Guo et L. L. Huang) N. H. Xia, in Flora of China, vol. 7: 74. 2008; T. B. Zhao et al. Shijie Yulanshu Zhiwu Ziyuan yu Zaipei Liyong: 191-192. fig. 9-3. 2013; T. B. Zhao et al. Shijie Yulanshu Zhiwu Zhongzhi Ziyuan Zhi: 26-27. fig. 3-5. 2013.

Magnolia multiflora M. C. Wang et C. L. Min, Acta Bot. Boreal. Occident. Sin., 12 (1): 85-86. fig. 1. 1992. Typus: C. L. Min 2611F, 2701 (NWFC, non vidi); Y. H. Liu, in Flora Reipublicae Popularis Sinicae Tomus 30 (1): 131. 1996; Y. H. Liu ed., Magnolias of China. 78-79. fig. t.. 2004. - Yulania multiflora (M. C. Wang et C. L. Min) D. L. Fu, J. Wuhan Bot. Res., 19 (3): 198. 2001; N. H. Xia et Y. H. Liu, Flora of China, vol. 7: 76. 2008; T. B. Zhao et al. Shijie Yulanshu Zhiwu Ziyuan yu Zaipei Liyong: 233-234. fig. 9-18. 2013; T. B. Zhao et al. Shijie Yulanshu Zhiwu Zhongzhi Ziyuan Zhi: 41-42. fig. 3-15. 2013.

Yulania dawsoniana subsp. dimorphiflora T. B. Zhao, J. T. Gao et W. X. Tian, Henan Yulan Zaipei: 161. t. 1: 2. 2015. Typus: No. 201304201 (HEAC).

Yulania glabrata var. multitepala Law et Q. W. Zeng, var. ined, Magnolias of China: 62. fig. Typus: non design. (IBSC)

Yulania campbellii var. alba auct. non Tresder: D. L. Fu et T. B. Zhao, in H. Jin et al. New records of Yulania Spach, Chinese Agricultural Science Bulletin, 21 (9): 313-314. 2005; in T. B. Zhao et al. Shijie Yulanshu Zhiwu Ziyuan yu Zaipei Liyong: 180. 2013; T. B. Zhao et al. Shijie Yulanshu Zhiwu Zhongzhi Ziyuan Zhi: 22. 2013; in T. B. Zhao et al., Henan Yulan Zaipei: 157. fig.9-1.2; t.1 (2.3.); t.12 (3.7.9.). 2015.

Deciduous trees to $26 \mathrm{~m}$ tall, $1.65 \mathrm{~m} \mathrm{~d}$. b. h., often of slender pyramidal or semi-globose habit; bark light tannish-gray, smooth and lenticellate, in old plants exfoliating in small flakes; branchlets stout to \pm slender, hornotini yellowish-green rare tannish-green, and greenish-yellow or 
brownish-yellow or with purplish-red aureoles when dried, pubescent to glabrous latter. Internodes of fruit 3 5 nodes $0.2 \sim 0.3 \mathrm{~cm}$ per node and gradually thickening, greenish-brown, two top-nodes often with two branchlets as pseudodichotomous branching. Foliar buds long ovoid, glabrous or sparsely puberulent, densely pubescent after outer perule exfoliating. Floral (mixed) buds terminal, ellipsoid or ovoid, $2.0 \sim 3.5 \mathrm{~cm}$ long and $1.0 \sim 1.8 \mathrm{~cm}$ in diameter, densely gray-white or gray-yellow villous, apices usually with a suddenly shrinking acumination about 2 5 mm long with closely adpressed hairs like brush heads. Leaves alternate, chartaceous, obovate or obovati-elliptic, 7.0 14.5 $(\sim 20.5) \mathrm{cm}$ long, 5.0 7.5 $(\sim 11.5) \mathrm{cm}$ wide; apices obtuse, truncate, with abruptly short-acuminate about 3 6 mm long; bases cuneate to broadly cuneate, sometimes oblique; upper surfaces deep green, nitid, glabrous, veins reticulate when dried; lower surfaces pale green, sparsely adpressed-puberulent and hairs $1.5 \sim 2.5 \mathrm{dmm}$ long, midveins obviously protuberant sparsely puberulent, lateral veins $8 \sim 13$ pairs, net veins reticulate; petioles glabrous $1.5 \sim 3.5 \mathrm{~cm}$ long, stipule scars short, $2 \sim 5 \mathrm{~mm}$

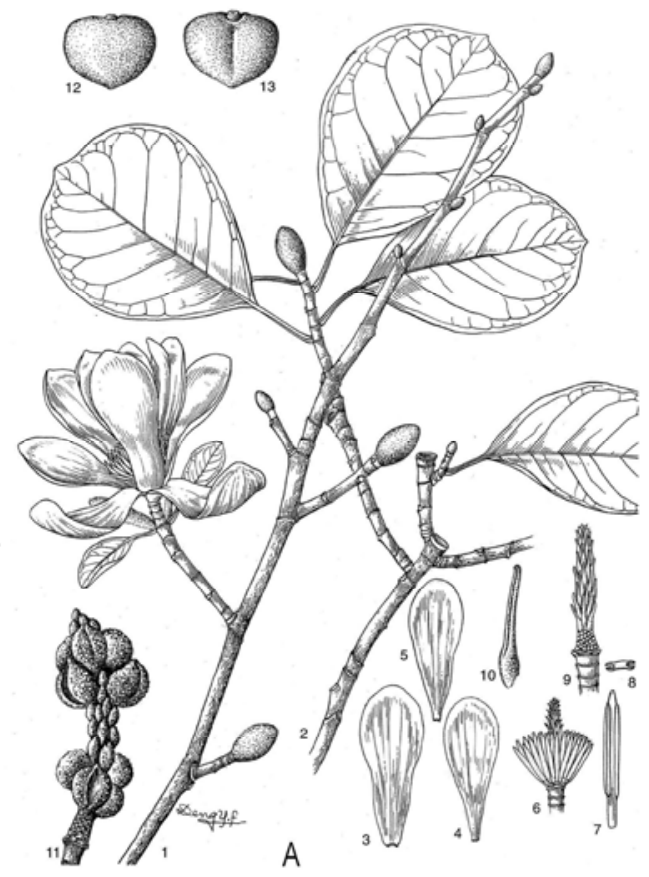

long or rarely to $1 / 2$ of the petioles. Flower precocious, fragrant, cup-shaped, held erect, to $12.0 \mathrm{~cm}$ in diameter; pedicels 3 9 mm long glabrous or densely villous. Tepals (9 ) 10 12 ( 14), subsimilar, petaloid, spathulato-oblong to spathulato-obovate, $6.0 \sim 9.0 \mathrm{~cm}$ long and $(1.5 \sim) 2.5 \sim 3.5 \mathrm{~cm}$ wide, white, the abaxial midveins pale purplish-red, bases pale purplish-red aureoles; the adaxial surfaces white. Stamens numerous $1.5 \sim 1.8 \mathrm{~cm}$ long, filaments pale rosy-red $2 \sim 5 \mathrm{~mm}$ long, anthers longitudinal dehiscing laterally, connected apices triangular short mucronate. Gynoecia cylindric, 2.0 3.0 cm long at anthesis, pale greenish-yellow; disjunctive-simplicial-pistils numerous, ovaries ovoid, styles and stigma yellowish-green or pale rosy-red, glabrous. Fruit aggregates long cylindric, often asymmetrical from seed abortion, $8.0 \sim 17.0 \mathrm{~cm}$ long, $2.5 \sim 3.0 \mathrm{~cm}$ in diameter; follicles globose, tuberculate, often with 1 seed developed, dehiscing into 2 valves after mature, gray-brown; Seeds red or orange-red, widely globose $8 \sim 10 \mathrm{~mm}$ long, 9 13 $\mathrm{mm}$ wide, endotesta about $8 \mathrm{~mm}$ long and $9 \mathrm{~mm}$ wide. Flower Mar to Apr, fruit Aug-Sept.

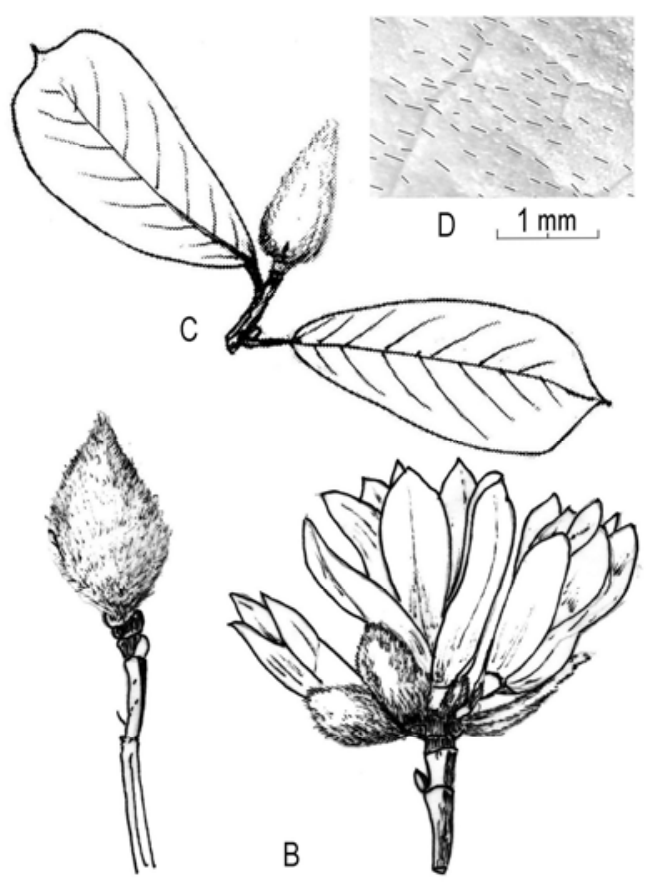

Figure 3. Yulania sprengeri (Pamp.) D. L. Fu. A. from Magnolias of China misidentified as Magnolia elliptigemmata C. L. Guo et L. L. Huang (drawn by Y. F. Deng), B. from Acta Bot. Boreal. Occident. Sin. misidentified as Magnolia multiflora M. C. Wang et C. L. Min (drawn by Z. M. Li), C. from Henan Yulan Zaipei misidentified as Yulania campbellii var. alba (drawn by T. B. Zhao), D. the lower surface of leaf to show sparsely puberulent (drawn by D. L. Fu).

The chloroplast complete genome of this species is mostly similar to Y. cylindrica (Wils.) D. L. Fu that has known (PHS $=0.993$, see Table 1).

Characteres specifici evolutionales typici: Ramuli hornotini flavo-virides rare tangerini-virides. Folia obovata apice saepe cum acumine subtus pallide viridia sparse puberula. Tepala $10 \sim 12$, subequalia.

The main typici-evolutionary characters are that the hornotini-branchlets yellowish-green rare tannish-green, the leaves obovate, apices usually acumens and lower surfaces pale green and sparsely puberulent, and the tepals 10-12, subsimilar.

It can be easily distinguished from the confusable species of Y. sect. Rosula D. L. Fu such as Y. diva, Y. urceolata, Y. pendula, Y. viridula, Y. sargentiana, Y. dawsoniana and Y. campbellii for its leaf puberulent but that of the confusable species pubescent or villous.

The species was described and illustrated as some new species or subspecies such as Magnolia elliptigemmata C. L. Guo et L. L. Huang [20], Magnolia multiflora M. C. Wang et C. L. Min [21], Yulania dawsoniana subsp. dimorphiflora T. B. Zhao, J. T. Gao et W. X. Tian [9], which all were nom. illegit. 
according ICBN (International Code of Botanical Nomenclature) [14].

The species was misidentified as Y. campbellii (Hook. f. \& Thoms.) D. L. Fu [7, 22], but the latter's lower surfaces of leaves usually tomentose not puberulent.

The species, a colloquial name Yingchunhua, is mainly distributed in deciduous broad-leaved forests at an altitude of 600 1700 m in Mountains Qinling and Mountains Daba of China, such as Mountain Baiyunshan in Luoyang, Wuduoshan and Baotianman in Nanyang of Henan province and Mountain Wudang of Shiyan, Shennongjia Forest Region, and Yuan'an county of Yichang of Hubei province, and Ningshan County of Shanxi province.

\subsection{Yulania Urceolata D. L. Fu, B. H. Xiong et X. Chen, sp. Segregat. Nov., Figure 4}

Magnolia sprengeri auct. non Pamp.: Y. H. Liu in W. J. Zheng (ed.), Flora of trees of China 1: 457-459. figure. 139. 1983; D. J. Callaway, The world of Magnolias: 145-148. 1994; Y. H. Liu, in Flora Reipublicae Popularis Sinicae Tomus 30 (1): 128. 130-131. t.31. 1996; Y. H. Liu (ed.), Magnolias of China. 112-113. figure. 2004. - Yulania sprengeri auct. non (Pamp.) D. L. Fu: Liu Y. H. et Xia N. H., in Flora Yunnanica. Vol. 16: 27. 2006; N. H. Xia et al., in Flora of China. 7: 72. 2008; T. B. Zhao et al., Shijie Yulanshu Zhiwu Ziyuan yu Zaipei Liyong: 187-189. 2013; T. B. Zhao et al., Shijie Yulanshu Zhiwu Zhongzhi Ziyuan Zhi: 25-26. 2013; T. B. Zhao et al., Henan Yulan Zaipei: 158-159. 2015.

Magnolia denudata auct. non Desr.: J. L. Zhang. Ancient and famous trees from Guizhou: 175. 2004.

Magnolia liliiflora auct. non Desr.: J. L. Zhang. Ancient and famous trees from Guizhou: 176-177. 2004.

Magnolia wufengensis L. Y. Ma et L. R. Wang, Bull. Bot. Res. (Haerbin), 26 (1): 4-6. Figures 1, 2. 2006. Type: No.45289 (BJFC). - Yulania wufengensis (L. Y. Ma et L. R. Wang) T. B. Zhao et Z. X. Chen, Shijie Yulanshu Zhiwu Ziyuan yu Zaipei Liyong: 192. 2013; T. B. Zhao et al., Shijie Yulanshu Zhiwu Zhongzhi Ziyuan Zhi: 27-28. 2013; T. B. Zhao et al., Henan Yulan Zaipei: 162. 2015.

Yulania cuneatifolia T. B. Zhao, Z. X. Chen et D. L. Fu, Bull. Bot. Res. (Haerbin), 30 (6): 643-644. Figure 2. 2010. Type: No.200503241 (HEAC); T. B. Zhao et al., Shijie Yulanshu Zhiwu Ziyuan yu Zaipei Liyong: 192. 2013.

Yulania zhaoyangyulan T. B. Zhao et Z. X. Chen, in T. B. Zhao et al., Shijie Yulanshu Zhiwu Ziyuan yu Zaipei Liyong: 235-236. figure. 2013. Type: No.20030328 (HEAC); T. B. Zhao et al., Shijie Yulanshu Zhiwu Zhongzhi Ziyuan Zhi: 45-46. 2013.

Yulania flexistylus T. B. Zhao et Z. X. Chen, nom. illegit., in

T. B. Zhao et al., Henan Yulan Zaipei: 159-160. 2015.

Yulania wugangensis auct. non (T. B. Zhao et al.) D. L. Fu: T. B. Zhao et al., Shijie Yulanshu Zhiwu Ziyuan yu Zaipei Liyong: t.9 (17). 2013; T. B. Zhao et al., Henan Yulan Zaipei: t.50 (3). 2015.

Yulania viridula auct. non D. L. Fu, T. B. Zhao et G. H. Tian: T. B. Zhao et al., Henan Yulan Zaipei: t.36 (1). 2015.

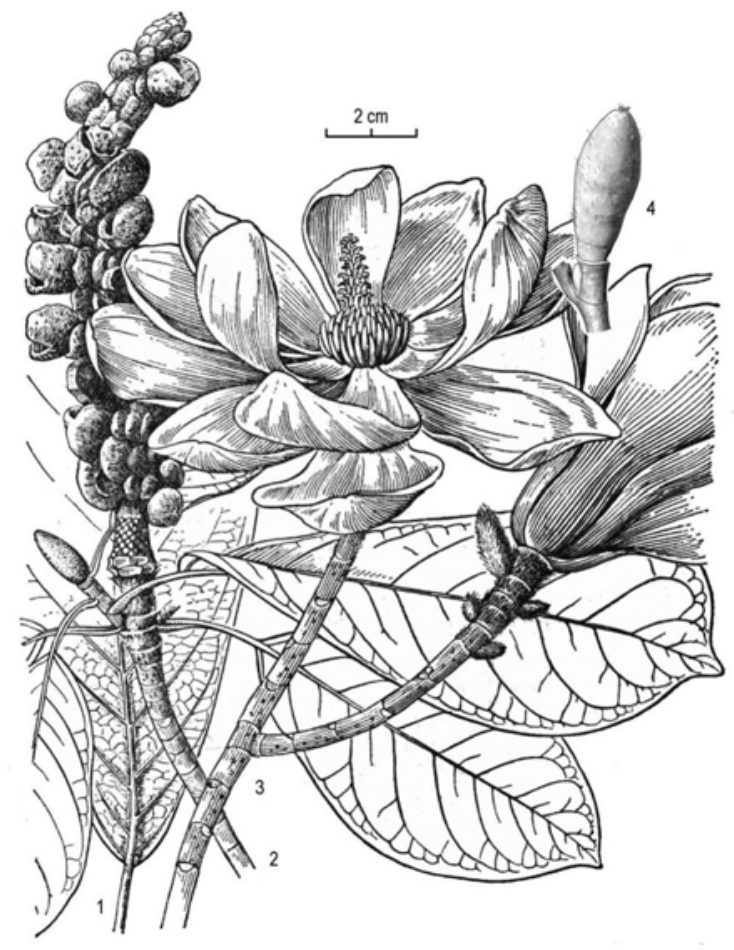

Figure 4. Yulania urceolata D. L. Fu, B. H. Xiong et X. Chen, sp. segregat. nov. 1. lower surface of leaf, show densely pubescent or villous along midvein, 2. branchlet with fruit, 3. branchlet with flower (from Flora of trees of China, drawn by Y. F. Deng,), 4. floral (mixed) bud. (drawn by D. L. Fu).

Arbor decidua. Ramuli crassi hornotini virides glabri nitidi, annotini virides, viridi-flavidi v. tangerini glabri nitidi, ramulis abbreviatis 4-6-nodis viridibus a basi ad apicem trapeziformi-incrassatis, lenticellis albis rotundis protuberantibus. Gemmae foliaferae longe ellipsoideae vel ovoideae sparse flavo-pubescentes ad glabriusculae. Alabastra solitaria, terminalia urceolata vel ellipsoideo-urceolata $2.0 \sim 3.0 \mathrm{~cm}$ longa et $1.0 \sim 1.4 \mathrm{~cm}$ diam.; perulae retentae saepe $1 \sim 2$, extus dense pubescentes. Folia alterna chartacea $6.5 \sim 17.0 \mathrm{~cm}$ longa et $3.0 \sim 9.0 \mathrm{~cm}$ lata obovata late oblanceolate elliptica vel ovato-elliptica apice acuminata vel acuta basi late cuneata margine integra supra atro-viridia glabra nitida costis sublevigatis vel leviter impressis glabris vel sparse pubescentibus subtus pallide viridia, sparse pubescentia vel dense villosa costis et nervis lateralibus dense pubescentibus vel villosis, nervis lateralibus 7 14-jugis; petioli $2.0 \sim 3.5 \mathrm{~cm}$ longi dense pubescentes ad glabri, cicatriculis stipularum longitudine $1 / 5 \sim 1 / 3$ petiolorum partem aequantibus. Flores ante folia aperti, 12.0 15.0 cm diam.; pedicelli $0.6 \sim 1.0 \mathrm{~cm}$ longi et $1.0 \sim 1.4 \mathrm{~cm}$ diam.; bractae 1 , $3.0 \sim 3.5 \mathrm{~cm}$ longa $2.8 \sim 3.0 \mathrm{~cm}$ lata extus albo-pubescentes; tepala (10) $12(\sim 16)$ in quoque flore, petaliformia subsimilia, anguste oblanceolato-elliptica, extus roseola intus alba, $6.5 \sim 9.0 \mathrm{~cm}$ longa et $1.5 \sim 3.2 \mathrm{~cm}$ lata; stamina numerosa ca. 110 in quequo flore, ochrica $1.2 \sim 1.4 \mathrm{~cm}$ longa, extus costis areolis pallide roseolis, thecis lateribus longitudinali-dehiscentibus, connetivis apice cum mucronibus triangulis ca. $1.0 \sim 1.5 \mathrm{~mm}$ longis; filamentis $4.5 \sim 5.0 \mathrm{~mm}$ longis rectangularibus pallide purpureo-rubris; gynoecium cylindricum ca. $2.2 \mathrm{~cm}$ longum, pistilla simplisia numerosis ca. 
130 in quequo flore, ovariis pallide flavo-viridulis glabris, stylis et stigmatibus extus pallide cinereis, stylis primo curvativis post rectis. Folliceta cylindrica scarlatina 10.0 16.0 $\mathrm{cm}$ longa et $2 \sim 3 \mathrm{~cm}$ diam. saepe curvata; semina cordiformia vel nephroidea $0.5 \sim 0.7 \mathrm{~mm}$ longa et $0.9 \sim 1.2 \mathrm{~cm}$ lata.

Lectotypus: Liu Yuhu in Zheng W J (ed.), Flora of trees of China 1: 459. fig. 139. Almost equal specimen, D. L. Fu 2017093001 (Paratypus, CAF) (branchlet with fruit, floral buds and leaves), Weining County of Guizhou Province of China. alt. 2300 m. 30. Sept. 2017; D. L. Fu 2009052401 (Paratypus, CAF) (branchlets with young fruits), D. L. Fu 2012032001 (Paratypus, CAF) (branchlets with flowers), Zhengzhou City of Henan Province of China, cultivated plants.

The chloroplast complete genome of this new species is mostly similar to Yulania diva (Stapf ex Dandy) D. L. Fu (NC023242.1) (PHS = 0.995).

The particularity of the new species: foliar buds glabrous or sparsely pubescent, floral buds urceolate or ellipsoideo-urceolate; fruit aggregates red and brown-purple when dried, and stamen scars on fruit receptacle obviously protuberant as thin verrucae, seeds widely nephroid, the width twice as length sometimes.

The new species is universally misidentified as Y. sprengeri (Pamp.) D. L. Fu in related botanical authorities, such as Flora of trees of China [13], Flora Reipublicae Popularis Sinicae Tomus [15], Flora of China [5], Shijie Yulanshu Zhiwu Zhongzhi Ziyuan Zhi [8], Flora Yunnanica [3] and so on, but its taxonomical characters such as that the foliar buds glabrous or pubescent, floral buds urceolate or ellipsoideo-urceolate pubescent or villous, and the leaf apices acuminate or acute, lower surfaces pubescent or villous, are obviously distinguished to the latter with the foliar buds glabrous or puberulent (gemmis foliiferis glabris vel ad apicem vix puberulis) [11], floral buds ovoid or ellipsoid long sericeo-villous (alabastris longe sericeo-villosis) [11], and the leaf apices obtuse with acumens and lower surfaces puberulent (the apices abruptly short-acuminate or rarely rounded ... lower surfaces ... finely adpressed-puberulent over the entire surface) [12]. So according to ICBN, the illustration (Figure 4.1 to 3 ), misidentified epitype of Y. sprengeri, is selected as lectotype with almost equal specimen collected from Guizhou and Henan province of China, which are renamed as a new species.

The species was described and illustrated as some new species such as Magnolia wufengensis L. Y. Ma et L. R. Wang [23], Yulania cuneatifolia T. B. Zhao, Z. X. Chen et D. L. Fu [24], and Yulania zhaoyangyulan T. B. Zhao et Z. X. Chen [7] based on holotypes collected in 2004, 2003 and 2005 respectively, which all are nom. illegit. according ICBN [14]. The illegitimate name Yulania flexistylus T. B. Zhao et Z. X. Chen [9] also belong to this species.

The species was also misidentified as Y. denudata (Desr.) D. L. Fu and Y. liliiflora (Desr.) D. L. Fu in Ancient and famous trees from Guizhou [25].

The species is distributed in the west of Guizhou, northeast of Yunnan, southwest of Hubei, and east of Sichuan province of China at an altitude of 1800 2400 m, colloquial names Hanlianhua, Eryuehua and Furonghua, for its beautifully red or pink flowers. Its floral buds are hard and brushlike, called woodenbrush in ancient China, and also called Xinyi, a Chinese traditional medicine.

The Chinese name of the new species is "Tantao Yulan". According to the "Shen Nong's Materia Medica" [26-30], "Houtao" (seasonal bud) was a alias of Xinyi (Chinese traditional medicine), which may be related to the phenology of Yulania (Xinyi plant) for its floral bud formed in summer and having different ornamental value until flowering in early spring of next year. The colloquial name Eryuehua of the species means not only it flowering in February (Lunar calendar), but also the red fruit like the February flower. So the author named the species "Tantao" for its floral bud shape and distinct phenological characteristics throughout the year.

\subsection{Yulania Pendula D. L. Fu, sp. Nov., Figures 5, 6}

Magnolia biondii auct. non Pamp.: in Flora of Qinling 1 (2): fig.288 (1.4.5.). -Yulania biondii auct. non (Pamp.) D. L. Fu: T. B. Zhao et al., Shijie Yulanshu Zhiwu Ziyuan yu Zaipei Liyong: fig.9-28 (1.4.). 2013; T. B. Zhao et al., Shijie Yulanshu Zhiwu Zhongzhi Ziyuan Zhi: fig.3-28 (1.4.). 2013; T. B. Zhao et al., Henan Yulan Zaipei: fig.9-29 (1.4.). 2015.

Magnolia sprengeri auct. non Pamp.: Y. H. Liu (ed.), Magnolias of China. fig.(1). 2004. -Yulania flexistylus nom. illegit. auct. non T. B. Zhao et Z. X. Chen: T. B. Zhao et al., Henan Yulan Zaipei: fig.9-2.2 (1). 2015.

Arbor decidua, ca. $20 \mathrm{~m}$ alta. Ramuli crassiusculi purpureo-tangerini hornotini viriduli vel flavo-viriduli glabri nitidi cum maculis alutaceis, lenticellis sparsis rotundis vel ellipticis; florum ramulis abbreviatis 3-6-nodis, internodis $0.5 \sim 1.2 \mathrm{~cm}$ longis, leviter incrassatis, viridibus, cum gemmis foliiferis $3 \sim 6,1$ in quoque nodis, gemmis magnitudine diversis a ramuli basi ad ejus apicem gradatim ampliatis, ea basali subglobosa ca. $0.2 \mathrm{~cm}$ in diam. pubescentibus, ea apicali claviformi $3.5 \sim 5.5 \mathrm{~cm}$ longa $0.5 \sim 1.0 \mathrm{~cm}$ in diam. dense incano-villosa. Alabastra solitaria, terminalia ellipsoidea longa dense flavo-lanosa, pilis $5.0 \sim 9.0 \mathrm{~mm}$ longis, cito ampliata ante anthesin; perulae saepe $1 \sim 2$ retentae, $6 \sim 8 \mathrm{~cm}$ longae et $4.5 \sim 6.0 \mathrm{~cm}$ latae extus dense flavo-lanosae; bracteae 1 rare 2, 5.5 6.5 cm longae et $3.0 \sim 5.5 \mathrm{~cm}$ latae extus a glabriusculae ad dense flavo-lanosae. Folia anguste elliptica crasso-chartacea vel subcoriacea $8.5 \sim 13.0 \mathrm{~cm}$ longa $4.0 \sim 6.0$ $\mathrm{cm}$ lata apice acuta, acuminata vel obtusa, basi cuneata margine integra supra atro-viridia nitida glabra, nervulis reticulatis in sicco, subtus pallide viridia costis dense albo-tomentosis, nervis lateralibus 8 12-jugis; stipulae lineares, $3.5 \sim 5.5 \mathrm{~cm}$ longae pendulae, dense flavo-pubescentes; petioli $1.5 \sim 4.0 \mathrm{~cm}$ longi; cicatriculis stipularum brevissimis ca. $3 \sim 5 \mathrm{~mm}$ longis. Flores ante folia aperti, macroformes $20.0 \sim 25.0 \mathrm{~cm}$ in diam.; pedicelli $1.0 \sim 2.0 \mathrm{~cm}$ longi et $0.7 \sim 0.8$ $\mathrm{cm}$ diam. sparse pubescentes, viriduli rare cum areolis pallide purpureo-rubris; tepala $12 \sim 15$ saepe 12 in quoque flore, 4 rare 5 in quoque verticillo, intime interdum 1 3, petaliformia subaequalia, anguste oblanceolato-elliptica, rubra vel roseola, $8.0 \sim 12.5 \mathrm{~cm}$ longa $2.5 \sim 4.5 \mathrm{~cm}$ lata paulatim tenuatis a basi ad 
apicem. Stamina numerosa ca. 120, 1.5 2.0 cm longa pallide flavodo-alba, utrinque costis atro-purpureo-rubris, thecis lateribus longitudinali-dehiscentibus, connetivis apice mucronibus triangularibus ca. $1.0 \mathrm{~mm}$ longis praeditis, filamentis ca. $5.0 \mathrm{~mm}$ longis rectangularibus atro-purpureo-rubris. Gynoecium cylindricum ca. $2.0 \mathrm{~cm}$ longum, pistilla simplisia numerosis ca. $80 \sim 100$, ovariis flavo-viridibus glabris, stylis et stigmatibus extus pallide cinereis intus albis stylis primo curvativis post rectescentibus. Folliceta cylindrica $11.0 \sim 14.0 \mathrm{~cm}$ longa et $2.5 \sim 3.5 \mathrm{~cm}$ diam. interdum curvata. Semina ossea subcordata vel depresso-globlsa ca. $9 \mathrm{~mm}$ longa et $8 \mathrm{~mm}$ lata.

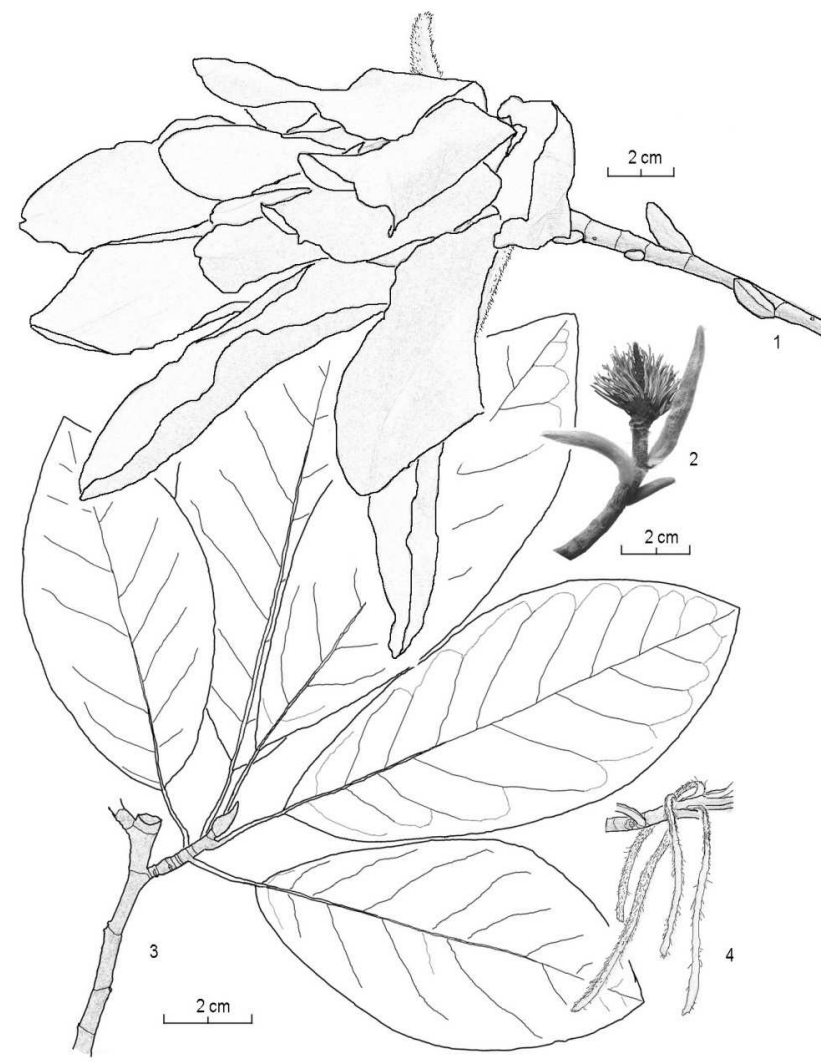

Figure 5. Yulania pendula D. L. Fu, sp. nov. 1. branchlet with flower, 2. branchlet with foliar buds and gynandrium, 3. branchlet with leaves, 4. young branchlet with pendulous stipules. (drawn by D. L. Fu).

Sichuan: Beichuan county, Guixi town, Linfeng village, Yaowang Valley, D. L. Fu 2012040201 (Holotypus, hic designatus, CAF) collected in a secondary forest, alt. $1200 \mathrm{~m}$. on Apr. 2, 2012; D. L. Fu 2012091308 (Paratypus, CAF) collected from the same tree on Sep. 13. 2012.

The chloroplast complete genome of this new species is mostly similar to Yulania viridula D. L. Fu, T. B. Zhao et G. H. Tian that has known (PHS $=0.995$, see Table 3 ).

The main typici-evolutionary characters of the species: the branchlets stout purplish-red and longitudinally fissured, hornotini-branchlets green or yellowish-green, floral buds large ellipsoid and densely long lanose, the leaves narrow elliptical and lower surfaces pale green, pubescent or villous at least at axils, the stipules linear and pendulous, and the tepals $12 \sim 15$, red, subsimilar.
The new typici-evolutionary characters of the new species: the foliar buds long columned obviously higher than the gynoecia and the stipules linear and pendulous before falling, which can be distinguished to all other species of genus Yulania Spach.

The new species is similar to Yulania carnosa D. L. Fu et D. L. Zhang [31], but its narrow elliptic leaves, pendulous stipules, long column foliar buds, membranous bracts are obviously distinguished to that of latter with ovato-round leaves, not pendulous stipules, ovoid foliar buds and carnose bracts.
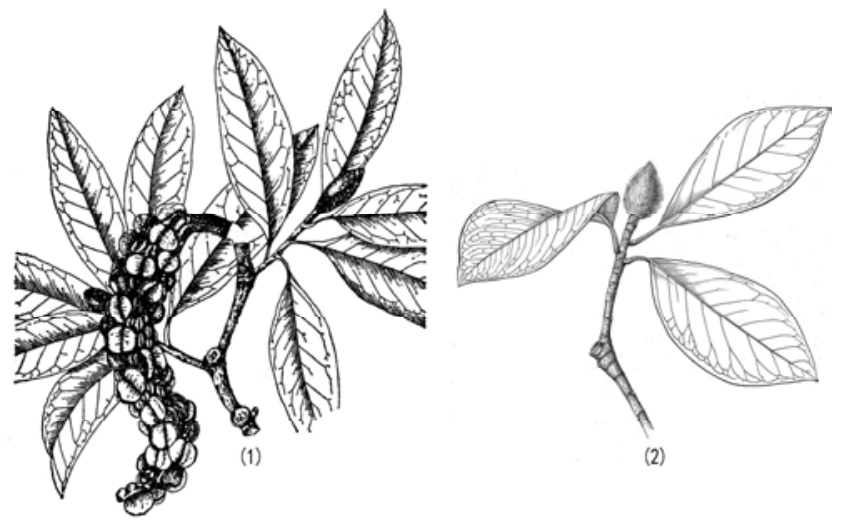

Figure 6. Yulania pendula D. L. Fu from misidentified illustrations in botanical authorities. (1) from Shijie Yulanshu Zhiwu Zhongzhi Ziyuan Zhi (Zhao et al., 2013), misidentified as Yulania biondii (Pamp.) D. L. Fu, (2) from Magnolias of China (Liu, 2004), misidentified as Magnolia sprengeri Pamp. $=$ Yulania sprengeri (Pamp.) D. L. Fu.

The species was misidentified as Yulania biondii (Pamp.) D. L. Fu (or Magnolia biondii Pamp.) in Flora of Qinling [32], Shijie Yulanshu Zhiwu Zhongzhi Ziyuan Zhi, etc. [7-9], but the flower of Y. biondii with 3 sepals and 6 petals not 12-15 petals and floral buds ovoid not ellipsoid (see Figure 6. (1)). The species was also misidentified as Magnolia sprengeri Pamp. in Magnolias of China [17], but the latter with leaves obovate and lower surfaces puberulent, not narrow elliptical and lower surfaces tomentose (see Figure 6. (2)).

The species is distributed in northeast of Sichuan province in deciduous broad-leaved secondary forest at an altitude of 1200 2000 m, and cultivated as a main species for Xinyi, a Chinese traditional medicine. So, it is named "Chuan Xinyi" in Chinese for that it was misidentified as Y. biondii (Pamp.) D. L. Fu and Y. sprengeri (Pamp.) D. L. Fu for many years in some botanical authorities and it was really mainly cultivated for "Xinyi" in North Sichuan Province.

\section{Conclusion}

The evolutionary system of Yulania Spach includes 4 natural sections: Y. sect. Yulania, Y. sect. Buergeria (Sieb. \& Zucc.) D. L. Fu, Y. sect. Rosula D. L. Fu, sect., nov., and Y. sect. Tulipastrum (Spach) D. L. Fu, which all have the same boundaries: PHS $(17 \mathrm{bp})=0.96$. The species Y. sprengeri (Pamp.) D. L. Fu belong to Y. sect. Yulania, but several confusable species such as Y. diva (Stapf. ex Dandy) D. L. Fu, sp. transl. nov., Y. urceolata D. L. Fu, B. H. Xiong et X. Chen, 
sp. segregat. nov., Y. pendula D. L. Fu, sp. nov. and Y. viridula D. L. Fu, T. B. Zhao et G. H. Tian belong to the new section of Y. sect. Rosula D. L. Fu. So, it can be scientifically solved by the genomic evolutionomy using the typical algorithm that the long-standing problem of the taxonomical confusion of Yulania sprengeri (Pamp.) D. L. Fu in the world.

According to International Code of Botanical Nomenclature, Y. sprengeri (Pamp.) D. L. Fu is proposed for conservation with a conserved type. Two new confusable new species, Y. urceolata D. L. Fu, B. H. Xiong et X. Chen, sp. segregat. nov., and Y. pendula D. L. Fu, sp. nov., are described and illustrated. Furthermore, two new translated species of Yulania genus, Y. stellata (Sieb. \& Zucc.) D. L. Fu, sp. transl. nov. and Yulania diva (Stapf ex Dandy) D. L. Fu, sp. transl. nov. are finally legitimately achieved. The evolutionary system of Yulania Spach scientifically overcomes the partial and subjective of past taxonomical systems of the genus.

\section{Acknowledgements}

This work was supported by the Fundamental Research Funds for the Central Non-profit Research Institution of CAF (CAFYBB2016MA009). The assembly and annotation of four chloroplast complete genomes of Yulania Spach were done by Henan Keyoushen Biotech Co., Ltd. We are grateful to Prof. Wencai Wang, the plant taxonomist and the academician of the Chinese Academy of Sciences, for his valuable suggestions and corrections in the Latin descriptions of two new species. We also thank Engineers of Jialin Chen and Qingyi An of Forest Bureau of Weining County of Guizhou Province, Ahou Laye et al. of Forest Bureau of Leibo County, Jin Zhou, Shunxiu Feng et al. of Forest Bureau of Beichuan County and Yugang Li of Forest Bureau of Hailuogou Tourism Economic Zone of Sichuan Province, Ziyang Sang et al. of Forest Bureau of Wufeng County, Zhengliu Wei et al. of Forset Bureau of Wudang Mountain Tourism Economic Zone, Dinglian Qu et al. of Forest Bureau of Shennongjia Forest Zone, and Daoman He and Sikuan Tan et al. of Forest Bureau of Yuan'an County of Hubei Province, Sanheng Jin, Yan Tian et al. of Forest Bureau of Nanzhao County and Zhanli Xie et al. of Forest Bureau of Songxian County of Henan Province, Zongkuan Luo et al. of Ningxi Forest Bureau of Shanxi Province, and Mr. Chen of Xuanwei County of Yunnan Province, et al. for their helps in investigating the plant resources.

\section{References}

[1] D. L. Fu. "Notes on Yulania Spach". Journal of Wuhan Botanical Research, vol. 19, no. 3, pp. 191-198, 2001.

[2] Z. Y. Wu, A. M. Lu, C. Y. Tang, Z. D. Chen, D. Z. Li. "A generality on the families and genera of Angiosperms in China". Beijing; Science Press, pp. 62-64, 2003.

[3] KIB (Kunming Institute of Botany). "Flora Yunnanica". vol. 16. Beijing; Science Press, pp. 25-30, 2006.

[4] G. H. Tian, D. L. Fu, D. W. Zhao, J. Zhao, T. B. Zhao. "Study on the Species Resources and New Classification System of
Yulania Spach”. Chinese Agricultural Science Bulletin, vol. 22, no. 5, pp. 404-411. 2006.

[5] N. H. Xia, Y. H. Liu, H. P. Nooteboom. "Magnoliaceae". In; Wu Z Y, P. H. Raven, Hong D Y. "Flora of China", Beijing; Science Press \& St. Louis, MO; Missouri Botanical Garden Press, vol. 7, pp. 71-77, 2008.

[6] N. H. Xia. "A New classification System of the Family Magnoliaceae". In; Xia N H, Zheng Q W, Xu F X, Wu Q G. Proceedings of the Second International Symposium on the Family Magnoliaceae. Wuhan; Huazhong University of Science \& Technology Press. pp. 12-38, 2009.

[7] T. B. Zhao, G. H. Tian, D. L. Fu, and D. X. Zhao. "Shijie Yulanshu Zhiwu Ziyuan yu Zaipei Liyong". Beijing; Science Press, pp. 179-383, 2013. [in Chinese].

[8] T. B. Zhao, Z. F. Ren, and G. H. Tian. "Shijie Yulanshu Zhiwu Zhongzhi Ziyuan Zhi”. Zhengzhou; Yellow River Conservancy Press, pp. 1-153, 2013. [in Chinese].

[9] T. B. Zhao, L. H. Song, G. H. Tian, and Z. X. Chen. "Henan Yulan Zaipei”. Zhengzhou; Yellow River Conservancy Press, 138-310, 2015. [in Chinese].

[10] D. L. Fu and H. Fu. "An evolutionary continuity principle for evolutionary system of organism divisions". American Journal of Agriculture and Forestry, vol. 6, no. 3, pp. 60-64, 2018. DOI: 10.11648/j.ajaf.20180603.14.

[11] R. Pampanini. "Magnolia sprengeri Pamp". Nouv. Giorn. Bot. Ital. n. ser. vol. 22, pp. 295, 1915.

[12] D. Hunt. "Magnolias and their allies". Sherborne; International Dendrology Society and The Magnolia Society, pp. 104-126, 1998.

[13] Y. W. Liu. "Magnoliaceae". In W. J. Zheng (ed.). "Flora of trees of China", vol 1. Beijing; Science Press, pp. 455-466. 1983.

[14] G. H. Zhu (translator). "International Code of Botanical Nomenclature (St. Louis Code)". Beijing; Science Press /St. Louis, MO; Missouri Botanical Garden Press, pp. 1-100, 2001.

[15] D. J. Callaway. “The World of Magnolias". Portland; Timer Press, pp. 135-174, 1994.

[16] Agendae ASE (ed.). "Flora Reipublicae Popularis Sinicae", Tomus 30 (1). Beijing; Science Press, pp. 126-141. 1996.

[17] Y. H. Liu. "Magnolias of China" . Beijing; Science Press, 44-55, 2004.

[18] N. Li., W. Huang, Q. Shi, Y. Zhang, and L. Song. "A CTAB-assisted hydrothermal synthesis of VO2 (B) nanostructures for lithium-ion battery application". Ceram. Int. vol. 39, pp. 6199-6206, 2013. DOI: 10.1016/j.ceramint.2013.01.039.

[19] M. Lohse, O. Drechsel, and R. Bock. "OrganellarGenomeDRAW (OGDRAW); A tool for the easy generation of high-quality custom graphical maps of plastid and mitochondrial genomes". Curr. Genet. vol. 52, pp. 267-274, 2007.

[20] C. L. Guo, L. L. Huang. "A new species of Magnolia medical plants from Hubei”. Journal of Wuhan Botanical Research, vol. 10, no. 4, pp. 325-327, 1992.

[21] M. C. Wang, C. L. Min. "A new species of Magnolia from Shanxi”. Acta Bot. Boreal.-Occident Sin., vol. 12, no. 1, pp. 8586, 1992. 
[22] H. Jin, B. S. Guo, B. Liu. "New Records of Yulania Spach from Henan Province". Chinese Agricultural Science Bulletin, vol. 9, pp. 613-614, 2005.

[23] L. Y. Ma, L. R. Wang, S. C. He, X. Liu, X. Q. Wang. "A new species of Magnolia (Magnoliaceae) from Hubei, China". Bull. Bot. Res. (Haerbin), vol. 26, no. 1. pp. 4-6, 2006.

[24] D. L. Fu, T. B. Zhao, Z. X. Chen, S. S. Chen. "Two New Species of Yulania Spach from Hubei Province of China". Bulletin of Botanical Research (Haerbin), vol. 30. no. 6, pp. 641-644, 2010.

[25] J. L. Zhang. "Ancient and famous trees from Guizhou". Guiyang; Guizhou Science \& Tech. Press, pp. 175-177, 2004.

[26] H. J. Tao (456-536, Liang Dynasty). "Famous Doctors (Replica)". Beijing; People's Health Press, pp. 64, 140, 1986.

[27] J. Su (Tang Dynasty). "Newly revised herbal medicine (659)
(Replica)". Hefei; Anhui Science \& Tech. Press, pp. 315-316. 1981.

[28] S. W. Tang (Song Dynasty). "Certificate of herbal medicine (1083)”. Beijing; Huaxia Press, pp. 358-363, 1993.

[29] S. Z. Li (Ming Dynasty). "Compendium of herbal medicine (1578)". Beijing; People's Health Press, pp. 1136-1137. 1957.

[30] Q. J. Wu (Qing Dynasty). "Research on the names and figures of plants (1848)". Shanghai; Commercial Press, pp. 1042-1044, 1959.

[31] D. L. Fu, D. L. Zhang, F. W. Li, J. H. Sun, and J. H. Ren. "Two New Species of Yulania Spach from Sichuan Province of China”. Bulletin of Botanical Research (Haerbin), vol. 30, no. 4, pp. 385-389, 2010.

[32] NIB (Northwest Institute of Botany). "Flora of Qinling", vol. 1. Seed Plants, no. 2. Beijing; Science Press, pp. 339, 1974. 